\title{
LANGUAGE ASSESSMENT FOR YOUNG LEARNERS
}

\author{
Oleh \\ Sumarni ${ }^{1}$
}

\begin{abstract}
Teaching English in Asia typically dominated by teachers and textbooks based. Even worse, teaching English for young learners is generally a matter of vocabularies memorization. The teaching focuses on short-term purposes, those are testing purposes. In fact, in teaching English, the assessment should focus on the function of the language itself. Those teaching styles might be caused by short-term purpose of teaching English: focuses on knowledge and memorization for testing purposes rather than communicative competence. Therefore all the teaching efforts focused on answering the tests while the primary function of learning English is being ignored. Memorizing vocabularies is general activities in teaching of English in primary level. Thus to avoid such shortterm purpose learning, a well and careful designed assessment should put into consideration in teaching English for young learners. Consequently the teaching-learning process will focus on authentic use of language. For those reason, authenticity in the assessment is a major consideration.
\end{abstract}

Key words: Teaching, young learners, assessment, authenticity

\section{Introduction}

The teaching of English in Indonesia is still mostly dominated by teachers. In contrast, learners tend to be passive and less involved in teaching learning process. Unlike other subjects, English is a subject that focuses on communication. Therefore an English teacher is not merely a subject teacher who teach the knowledge, but a teacher who teach primary function of language: communication.

In one hand, English becomes "highly recommended" subject; on the other hand the teaching of English focuses more on the knowledge rather than

\footnotetext{
${ }^{1}$ Sumarni adalah dosen Jurusan PBS FKIP Untan
} 
the usage. Books for language teachers of English have been intensely written and used nationwide for school purposes in our country from play groups to high schools. Accordingly, books available at bookstores and used by the majority of school teachers may not completely fit their English programs for all Indonesian learners.

When looking closely at most primary English school textbooks, particularly used for Indonesian beginners, vocabulary is still taught as isolated words. In fact, the teaching of vocabulary should be integrated into the four skills-listening, speaking, reading, and writing (Linse, C, 2006). Besides that, some topics mismatch with the learners' experience, for example the word train for most learners in Kalimantan, it is not a familiar words for they do not have any experiences about train. In other words, the contexts of the teaching materials are not familiar for them. Therefore, instructional design for young learners should be designed carefully based on the philosophy of young learners.

Besides, the materials in teaching, learning styles (as well as teaching styles) also play an important role in language teaching. In most Asian countries, traditionally, the teaching of EFL is dominated by a teachercentered, book-centered, grammar-translation method and an emphasis on rote memory (Liu \& Littlewood, 1997). In most of reading classes, for instance, the students read new words aloud, imitating the teacher. The teacher explains the entire text sentence by sentence, analyzing many of the more difficult grammar structures, rhetoric, and style for the students, who listen, take notes, and answer questions.

These traditional language teaching approaches have resulted in a number of typical learning styles in East Asian countries. In East Asia, most students see knowledge as something to be transmitted by the teacher rather than discovered by the learners. They, therefore, find it normal to engage in modes of learning which are teacher-centered and in which they receive knowledge rather than interpret it. According to Harshbarger et.al (1986 cited in Zen, 2001), Japanese and Korean students are often quiet, shy and reticent in language classrooms. They dislike public touch and overt displays of opinions or emotions, indicating a reserve that is the hallmark of introverts. Chinese students likewise name "listening to teacher "as their most frequent activity in senior school English classes (Liu \& Littlewood, 1997).

This situation is similar to language teaching in Indonesia, in which focus mostly English as knowledge subject (as other subjects): social sciences, 
Science, mathematics) rather than its primary function: communication. Sue and Kirk (1972), stated that many Asian students are less autonomous, more dependent on authority figures and more obedient and conforming to rules and deadlines. As a result, Asian students are tend to be reluctant to "stand out" by expressing their views or raising questions, particularly if this might be perceived as expressing public disagreement (Song, 1995).

Another characteristically East Asian learning style is visual learning. It is obvious that such visual learning style stems from a traditional classroom teaching in East Asia, where most teachers emphasize learning through reading and tend to pour a great deal of information on the blackboard. Students, on the other hand, sit in rows facing the blackboard and the teacher. Any production of the target language by students is in choral reading or in closely controlled teacher-students interaction (Song, 1995 cited in Zen 2001). Thus, the perceptual channels are strongly visual (text and blackboard), with most auditory input closely tied to the written.

Those teaching styles might be caused by the purpose of teaching English. It is a common that the purpose of teaching is short-term purpose. It is able to do the test well. Therefore all the teaching efforts focused on answering the tests. Therefore, the teaching only focuses on knowledge and memorization rather than communicative competence. In fact the purpose of teaching English is communicative competence. As a result the teaching of English in most primary level is mostly a matter of memorizing vocabularies. Thus to avoid such short-term purpose learning, the assessment should put into account. A well and careful designed teaching and assessment should put into consideration in teaching English for young learners. Consequently the teaching-learning process will focus on authentic use of language. Authenticity in assessing the learners, the assessment is a major consideration.

\section{Assessment Young Language Learners}

Teachers need to know the result of the teaching-learning process. In other words, teacher need to identify whether the teaching-learning process is successful or not. Therefore assessment is required for this purpose. Assessment refers to collecting information, and making judgments on a learner's knowledge. Assessment and evaluation is different. Evaluation is used to interpret information for making decisions (Linse, 2006:138).

How about test? Assessment and Testing are not synonymous terms (Brewer, 2007:202). Further he mentioned that assessment is more than 
testing. A test is a method of measuring a person's ability, knowledge, or performance in a given domain (Brown, 2004: 3). Therefore, a test:

1. is a method;

2. must measure;

3. measures individual's ability;

4. measures a given domain.

A good teacher always assesses students whether incidental or intended (Brown, 2004:4). Figure 1 shows the relationship among testing, teaching and assessment.

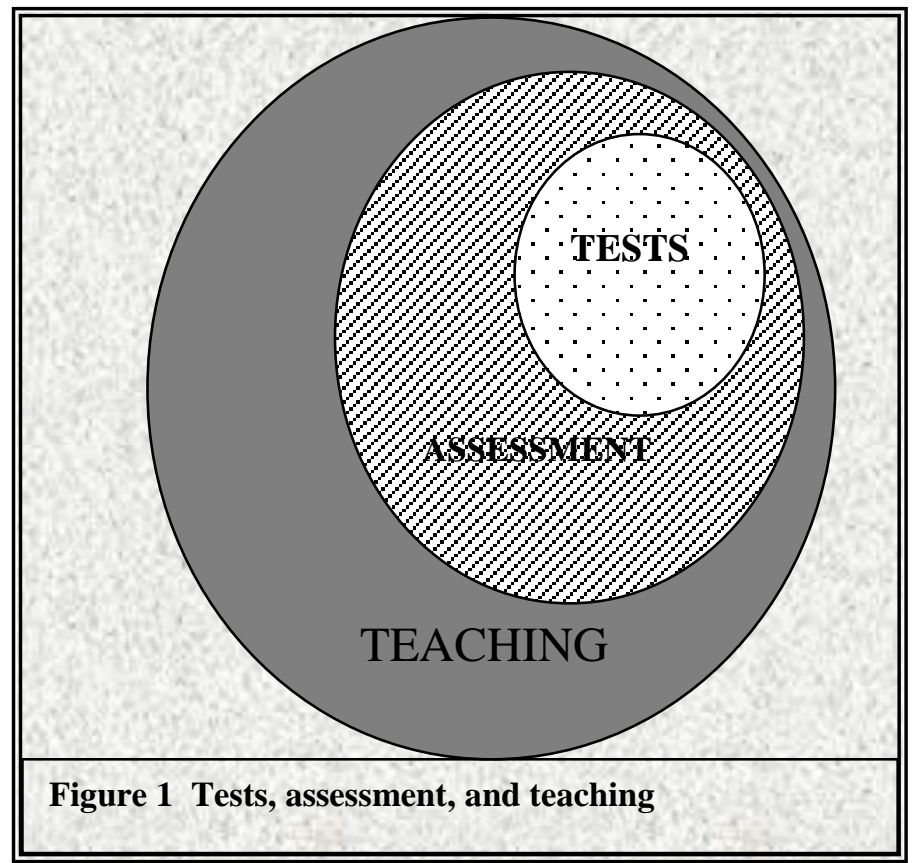

(Taken from Brown, 2004:

Effective English teacher will automatically assess learners and unconsciously will notice which learners found the content too difficult which ones found it too easy. Then, teacher will guide the learners (who found it is difficult) by rephrase or given more time answer. In contrast, if learners can answer quickly, teacher should ask a more challenging question. 
Assessment is part of teaching and learning. Teacher always assess the learners, planned or unplanned, formal or informal. Experienced teacher will notice that the learners understand the concept or not. From figure 1, it is clear that assessment denotes a big portion in teaching.

I. Informal and Formal Assessment

Assessment is an ongoing process. It may take place in any part of language teaching. Assessment may be informal and formal.

A. Informal Assessment

Informal assessment can take a number forms, starting with incidental, unplanned comments and responses, along with coaching and other impromptu feedback to students (Brown, 2004: 5 The examples are various, “Good job!", "Did you say can or can't?", "Do you mean sheep?", or simply put a $(;)$ or a $:$ in their work. Again, Brown (2004:5) believed that assessment does not stop here, a good deal of teacher's informal assessment is embedded in classroom tasks designed to elicit performance without recording results and making fixed judgments about the student's competence.

B. Formal Assessment

Formal assessments are exercises or procedures specifically designed to tap a storehouse of skills and knowledge. Therefore, it is systematic, planned sampling techniques constructed to give teacher and students an appraisal of student achievement (Brown, 2004: 6). All tests are formal assessments, but not all formal assessments is testing. For example is the use of students' journal writing or portfolio of materials as formal assessment. Those assessments are not tests. This similar to observation made to assess students' oral participation in class. Absolutely, this is not a test but it is formal assessment.

Other formal assessments are assessment mandated by Ministry of Education, State or local school. In country where English is Foreign Language, test like the Cambridge Young Learners Test (administered by the University of Cambridge ESOL Examinations) has been introduced. This is one of standardized test.

\section{Principles of Language Assessment}


Two essential concepts in discussing assessment are: validity and reliability besides other principles practicality and authenticity.

A. Practicality

An effective test is Practical. Consequently, it:

1. is not excessively expensive,

2. stays within appropriate time constraints,

3 . is relatively easy to administer, and

4. has a scoring/evaluation procedure that is specific and timeefficient

B. Reliability

Reliability refers to the consistency of the test over a period of time. It means that the results of the test will consistent even other teacher administer the test and/or different teacher score them. However, the result may not be identical but similar (Hughes, 1989 cited in Linse, 2006: 140 \& Brown, 2004:20).

C. Validity

It is considered valid if measures the skill it is supposed to measure with a specific group of learners. Brown (2004:20) affirmed that the most complex of an effective test_and the most important principle_is validity. Gronlund (cited in Brown, 2004:20) defined validity as, "the extent to which inferences made from assessment". A valid test of speaking ability must measure speaking ability. To determine whether certain assessment activity is valid or not, teacher need to look at what the activity is and how it supposed to measure. Figure 2 shows the assessment activity and the skill assessed by each activity (Linse, 2006:140)

\begin{tabular}{|l|l|}
\hline \multicolumn{1}{|c|}{ Assessment Activity } & Skill Assessed \\
\hline $\begin{array}{l}\text { Learners put all of the pictures that } \\
\text { start with the /t/ sound together. }\end{array}$ & Phonemic awareness \\
\hline $\begin{array}{l}\text { Learners match a written word with } \\
\text { the picture. }\end{array}$ & Reading/ Vocabulary \\
\hline $\begin{array}{l}\text { Learners listen to a story and then } \\
\text { answer comprehension questions, }\end{array}$ & Listening comprehension. \\
\hline
\end{tabular}


Figure 2. Assessment activity and skills chart.(Linse, 2006:140)

It is also important to determine the learners who will take the test. Test for learners in urban areas may be not valid for learners in rural areas. This also happens to beginning learner of age eleven to thirteen and those six to eight year olds. Although, they are similar in terms of their English proficiency, their intellectual developments are different.

D. Authenticity

Authentic means genuine, real not artificial. In language test, authentic means that it can be applied in real life activities. Bachman and Palmer (cited in Brown, 2004:28) defined authenticity as "the degree of correspondence of the characteristics of a given language test task to the features of of a target language task".

In order to construct authentic task, some consideration should be taken into account:

1. The target language is the test as natural as possible.

2. Items are contextualized rather than isolated.

3. topics are meaningful (relevant, interesting) for the learner.

4. Some thematic organization to items is provided, such as through a story line or episode.

5. Tasks represent, or closely approximately, real-world tasks.

(Brown, 2004:28)

III. Types of Assessment

Based on its function, assessment can defined as formative and summative assessment.

\section{A. Formative assessment}

Formative assessment use to form the learners competencies and skills with the goal of helping them to continue that growth process (Brown, 2004: 6). Formative assessment is useful for it may help teachers adjust their instruction and makes changes, if needed for individual students (Brewer, 2007: 203). Formative assessment use to check on the progress of one or more children many times everyday.

B. Summative Assessment 
Summative assessment occurs at the end of teaching unit, a period of time, or topic. Therefore, adjustment can no longer be made in instruction. Summative assessment use periodically to determine if the children have met certain benchmarks at a given time (Brewer, 2007: 203).

IV. Background to assessing Young Learners

Besides those principles above, there are some additional considerations in planning language assessment.

1. Reasonable expectations

The expectation for the learners should be reasonable and realistic. For example, to expect the learners be fluent in English after few semesters while they only have English class between 2-5 hours a week.

2. Wait time

Give time to learners to think and respond questions. At least learners need to think five seconds. Do not interrupt them, beefier they have time to process the information and form an answer. If you do so, you will not only miss the opportunity to assess but only it signs that you think they do not the answer.

3. Transitioning into English

EFL learners tend to think in their native language, therefore give them time to transit their thought into the target language.

4. Instructions to learners

The instruction for young learners must be clear, short sentences, and easy to understand. The instruction should be easy to understand as, sometimes learners may know the answer but do not understand the instructions. The vocabulary used must be familiar for them and appropriate to their age and proficiency level. See example in figure 3.

\begin{tabular}{|c|c|}
\hline Poor Instructions & Good Instructions \\
\hline $\begin{array}{l}\text { Look at the list of vocabulary } \\
\text { items and circle the } \\
\text { corresponding letter of the item }\end{array}$ & $\begin{array}{l}\text { Look at the list of words. One } \\
\text { word does not belong. Circle } \\
\text { the letter of the word that does }\end{array}$ \\
\hline
\end{tabular}




\begin{tabular}{|l|l|}
\hline $\begin{array}{l}\text { which does not belong. Note } \\
\text { that one word is dissimilar. }\end{array}$ & not belong.. \\
\hline Sample item & Sample item \\
a. cat & a. cat \\
b. bird & b. bird \\
c. house & c. house \\
d. fish & d. fish \\
\hline
\end{tabular}

Figure 3. Test Instruction (Linse, 2006: 142)

Assessment for young learners should be carefully designed. Assessment has an essential role in determining the teaching learning success. Therefore, assessment is not merely a test but it will indicate the learners' knowledge, skills, or concepts of the materials given by teachers.

\section{Conclusion}

Teaching and assessing English for Young Learners (TEYL) should be carefully designed as Brown (2001: 87-90) proposed some practical approaches in teaching young learners: intellectual development, attention of span, sensory input, affective factors, and authentic, meaningful language. The assessment should be in line with the learning objectives, materials, and activities.

English teacher of young learners, know their learners characteristics. A shy and quiet learner should treat differently from those extrovert learners. The teaching design should develop in a way that is suitable for the learners not merely from the books available. Meaningful and contextual learning are the primary consideration in designing the instructional design.

The teaching materials should develop in such a way, from the simplest to more complex ones, from very basic language skills. In this case it should be started from natural language use. The instructional designs start from listening to writing. The assessment should be in line with the process, the learning objectives as well as the authentic of language use whether it is formal or informal assessments. 
At the end, English teacher is different to other subject teachers. For language teacher, the crucial characteristic is to enable learners to be able to use the language as its primary function: communication.

\section{Reference}

Brewer, J.A., 2007. Introduction to Early Childhood Education: Preschool to Primary Grades, $6^{\text {th }}$ edition, Boston: Pearson Education, Inc.

Brown, H.D., 2001. Teaching by Principles: an Interactive Approach to Language Pedagogy, $2^{\text {nd }}$.edition, NY: Addison Wesley Longman, Inc.

Brown, H.D., 2004, Language Assessment: Principles and Classroom Practices, White Plains, NY: Pearson Education. Inc.

Cameron, L. 2001. Teaching Languages to Young Learners. Cambridge: Cambridge University Press.

Ellis, R. 2003. Task-based Language Learning and Teaching. Oxford: Oxford University Press.

Linse, C.T., 2006. Practical English Language Teaching Young Learners, Nunan, D. (eds) Boston: McGraw Hill.

Liu, N. F. and Littlewood, W. 1997. Why do many students appear reluctant to participate in classroom learning discourse? System, 25/3, 371-384.

Zen H, 2001.Matching Teaching Styles with Learning Styles in East Asian Contexts, The Internet TESL Journal Vol. VII, No. 7, July 2001, viewed at June, 16, 2005 Available at: http://iteslj.org/Techniques/Zhenhui-TeachingStyles. 